\title{
Combating Examination Malpractices in the Basic Education Certificate Examinations (BECE) in Ghana
}

\author{
Derick Folson \\ Department of Mathematics, \\ Kwame Nkrumah University of Science and \\ Technology, Kumasi-Ghana
}

\author{
Francis Kwadwo Awuah \\ Institute of Science and Technology Education, \\ University of South Africa, South Africa
}

\begin{abstract}
On annual basis, WAEC furnish Ghanaians with a stunning number of candidates who are caught cheating in their examinations. WAEC cancels the results of such candidates and even hand some culprits over to the Police for prosecution at the courts. But cheating continues and in most cases, increases year by year. There has been allegations and counter-allegations as to how and why these examination malpractices is on the increase in Ghana. In an attempt to unravel the mysteries of malpractices surrounding the conduct of the Basic Education Certificate Examinations (BECE), funding was sought from education-oriented Nongovernmental Organisations (NGOs) and recruited thirty fresh graduates from Ghanaian universities and guided them to gain teaching appointments in schools that are noted by the community to indulge in examination malpractices, but for one reason or the other, has never been caught red-handed. The accounts of these thirty recruits spread across all the ten regions of Ghana forms the basis of this paper.
\end{abstract}

\section{General Terms}

ICT, Examination Malpractice, Cheating

\section{Keywords}

WAEC, Malpractice, BECE,

\section{INTRODUCTION}

Examination and academic dishonesty form substantial part of challenges facing the conduct of academic examinations worldwide. Prominent among academic dishonesty is examination malpractices. Examination malpractices are multi-dimensional, which can occur at any stage of public examining process spanning from planning, test designing/construction, administration, scoring/marking, grading and dissemination of results [1]. Ghana has had its own share not only in internally conducted examinations, but also the West Africa Examinations Council (WAEC) conducted examinations. It is only natural that ill-prepared and poor students develop the propensity to cheat in an examination as the only means of covering up for their ineptitude. The Basic Education Certificate Examinations (BECE) is conducted for grade nine (9) students as a means of assessing and consequently placing them in the secondary and technical schools in Ghana for further training. A cursory look at the BECE results as released by WAEC shows a worrying trend in general performance. For instance, in 2008, the pass rate of BECE candidates was $62.16 \% ; 60.21 \%$ in 2009; $49.12 \%$ in $2010 ; 46.93 \%$ in 2011 and $99.93 \%$ in 2012 . The clear anomaly in performance trend in 2012 made every concerned Educator know that cheating was being encouraged in gigantic proportions even by people in high office of government as a means to cover for the poor attention being given to the basic students. With 2012 being a critical election year in the annals of the nation, government had no option than to put their critics wrong by achieving unprecedented performance for students in the BECE to prove to all that it was, indeed, doing their best for the educational sector. Such poor performances among BECE candidates over recent years suggest that cheating will become rampant. This is against the back drop that some heads of senior high schools and concerned educators in the country have observed that there is no match between the apparently high achievement of pupils in the BECE and their performance at the senior high school level, and for that reason criticized the validity of the BECE [2]. In the past, examination malpractice was mostly in the form of students smuggling foreign materials into the examination room but this has transmogrified into more complex forms. For instance, WAEC alludes to reports of other forms of examination malpractice and irregularity the most prominent of which was collusion/assisted cheating involving teachers, invigilators, supervisors, and even proprietors of schools [3]. The report went even further to mention Ghana as having another emerging form of examination malpractice which involves the deliberate registration of unqualified candidates by school authorities. This canker of examination malpractice has become a booming business that it could be inferred that there are examination fraud cabals who make brisk business by engaging in the unholy act [4].

WAEC has over the years worked assiduously towards making their examination results reflect upon the performance of its candidates by instituting some mechanisms to curtail the incidence of examination malpractices and to make the act unattractive. Nevertheless these mechanisms have not been as effective as had been envisaged. In 2009, 525 candidates sanctioned for their involvement in various kinds of examination malpractice more than doubled to 1,083 candidates in 2010. The figure then increased to 1,127 in 2011 before dropping to 823 in 2012 [5].

Bribery of examination officials such as invigilators, supervisors, etc who are directly involved in the conduct of examinations by candidates, parents, and even proprietors is a corruption that needs to be eliminated. No matter how corruption is defined, it weakens societies, impacts and hinders social and economic development. It diverts domestic and foreign investment away from where it is needed; it weakens education and health systems; exacerbates inequality; distorts electoral processes and undermines government institutions [6]. Monopolies and discretion are corruption facilitators, while accountability and an anti-corruption ethical ambience in communities are inhibiting factors. There are several ways in which ICT can contribute positively to changes regarding these factors [7]. The West African Examination Council has not lost the fact that ICT can help 
them improve upon the integrity of its examinations. In their 2009 Annual Registrars Report, they stated clearly that, the Secretariat has continued to explore the many possibilities that ICT offers for the enhancement of the quality of our services. The anomaly in results of 2012 BECE candidates is a cause for concern as the pass rate of $99.93 \%$ immediately raises eyebrows. Again, the massive drop of number of candidates involved in examination malpractice sought to confirm that more people succeeded in cheating but were never caught or just cautioned by word of mouth. The aim of this research is to ascertain the tricks adapted by candidates, invigilators, proprietors and other bodies concerned in the conduct of BECE, and find ways of circumventing this menace with the aid of ICT. Available ICT tools will also be examined and the shortfalls associated with these tools will be looked into with the view of proposing ICT solutions that is acceptable to all for the simple reason that it is fail-proof.

\section{RESEARCH METHODOLOGY}

Following the public outburst of alleged fraud in the conduct of the 2012 BECE, funding was sought to investigate how deep the problem was (if any) and find ways of curbing this menace. Thirty university graduates were recruited, trained, and assigned the role to seek for employment as teachers in schools that were perceived to be spearheading the malpractice across all the ten regions of Ghana, namely Greater Accra Region, Ashanti Region, Brong-Ahafo Region, Central Region, Eastern Region, Northern Region, Upper East Region, Upper West Region, Volta Region and Western Region.

Provision was made to have access to laptop computers and mobile communication devices to receive periodic briefings from these recruits. As a result of the high academic qualifications of these recruits, these suspected schools were willing to give them high responsibilities of preparing final year students for the upcoming BECE. Nine (9) of our recruits had the opportunity of gaining the total confidence of headteachers and proprietors of their respective schools and so were made to lead their final year candidates to the exams centre throughout the six days the exams lasted. Seventeen (17) members of the team were also made to be among the team that took the students to the exams centre only if their subject of teaching were being taken. Four members of our team were never given the opportunity to be at the exams centre because their schools thought they were too new to be let in into their private activities.

Of the nine (9) who headed their school to the examination centres on daily basis, two (2) each were in Ashanti Region, Brong Ahafo Region, and Central Region. Greater Accra Region, Northern Region, and Volta Region had one (1) each of our recruits leading them to the examination centres. The other seventeen (17) who went to exams centre on the account of their paper being written, eight out of nine subjects, with the exception of French Language, were under their watch in totality, were spread across all the ten regions of Ghana.

In all, thirty private schools were investigated. The table below shows the regional distributions of our recruits to these schools.

Table 1. Regional distribution of recruits.

\begin{tabular}{|l|c|}
\hline \multicolumn{1}{|c|}{ Region } & Population \\
\hline Ashanti Region & 5 \\
\hline Greater Accra Region & 3 \\
\hline Brong-Ahafo Region & 4 \\
\hline Western Region & 3 \\
\hline Central Region & 2 \\
\hline Eastern Region & 3 \\
\hline
\end{tabular}

\begin{tabular}{|l|l|}
\hline Volta Region & \multicolumn{2}{|c|}{3} \\
\hline Upper East Region & 2 \\
\hline Upper West Region & 2 \\
\hline Northern Region & 3 \\
\hline
\end{tabular}

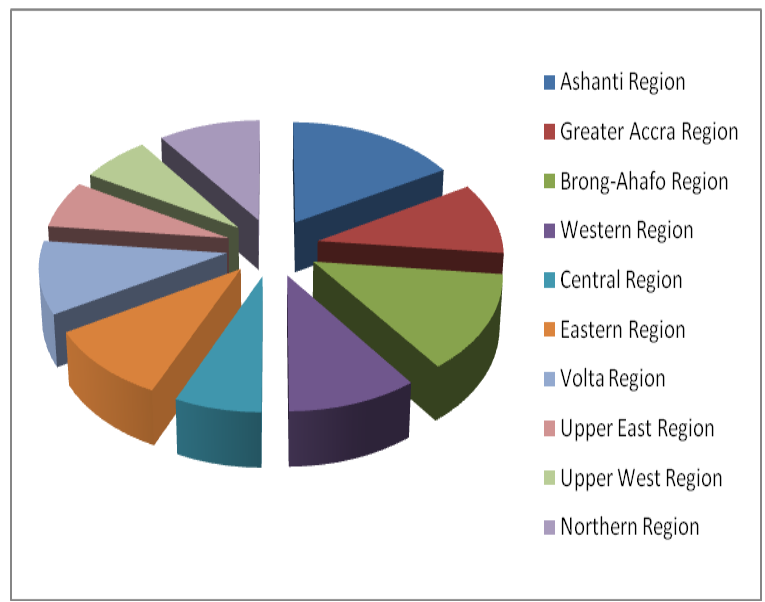

Fig 1: Regional distribution of researchers

The personal account of these recruits, backed by electronic evidence, forms the content of this research paper.

\section{A BRIEF HISTORY OF GHANA'S EDUCATIONAL SYSTEM}

The History of education in Ghana dates back to 1592 . Initially it was the Danish, Dutch and English merchants who set up schools in their Forts (Christianborg Castle AccraDanish, Elmina Castle-Portuguese then Dutch and Cape Coast Castle-British) to educate their mulatto children by native women.

John Von Richelieu, one of the Danish Governors to Ghana, approached the Basel Mission Society of Switzerland in 1828. They played an important role in establishing an education network in Ghana. Representatives of this organisation were able to convince the Chiefs of Ghana in 1832 to send their children to the Government School at Osu. Thus creating acceptance for formal education. They also concentrated on the interior of Ghana, away from the European influences on the coast. By 1894, 62 years after their arrival in Ghana, they had established a Training College, 3 grammar schools, seven boarding schools for boys and girls and 98-day schools.

In 1874 the British Government had full colonial authority of the Gold Coast colony. Already great progress had been made in the education sector. Various Mission Schools were now scattered over the interior of Ghana.

By 1881 there were 139 schools. However the education systems used varied widely. This prompted the government to draw up its first plans in the 1882 to guide the development of education. An Inspector of Schools was instated from 1887 until 1890. Then the office of the Director of Education was created.

In 1918 the first real targets for the development of education were set by Sir. Hugh Clifford:

- Primary education for every African boy and girl

- A Training College for teachers in every province

- Better salaries for teachers

- A Royal College

Ultimately the proposed targets and recommendations from several committees such as 'the Phelps-Stokes Fund' from America and the "1922 Committee" led to the opening of the Prince of Wales College in 1927. Later it became the 
Achimota College. It offered general secondary education as well as post secondary technical education and teachers training for both sexes.

Great strides were made on the education front from 1922 till 1938. Several Industrial Schools were established, focusing on technical and agricultural education. A separate Department of Education was instated to bring the neglected Northern territories in tune. At the Prince of Wales College scholarships were awarded to students to continue their studies in British universities.

By 1933 an important emphasis was placed on the training of teachers by the government. Also several local languages were approved as examinable subjects for the Cambridge University School Certificate. Many different topics such as domestic science, child welfare, bookkeeping and typewriting found their way into the secondary education system.

By the 1950 s there were approximately 3000 primary and secondary schools in Ghana and $6.6 \%$ of the 4.2 million population was in School. The British laid a solid foundation for the formal education system in Ghana, however only a small group had access to it. The Nkrumah Government in 1952 saw education as a major instrument for national development and implemented the policy of education for all proposed by Sir. Hugh Clifford in 1918.

Until 1968, the Ghanaian educational system was made up of 6 years of primary, 4 years Middle School, $4 / 6$ years Secondary school and 3 years tertiary education. Successful students in a Common Entrance Examination or the Middle School Leaving Certificate Examinations were admitted into the Secondary school to pursue a four-year secondary education, and a two-year sixth form course. In order to address concerns raised about the time spent in pre-tertiary education, it was proposed that children be selected to secondary school after six years of primary education.

A new system known as Continuation School was introduced in 1968 to replace the Middle School system, which aimed at making the elementary school system practical-oriented. This system was an attempt to provide practical job training to school leavers to provide employment for the youth. It was also aimed at eliminating the rush for white-collar jobs which were becoming more scarce in the country. The continuation school system at this point (end of the 1960s) consisted of six years of primary education, followed by four-years of secondary education. At the end of the four years, suitable students went on to do a two-year sixth form course that could lead to a three-year University course. Students, who were not suitable to continue into sixth form education, completed twoyears of pre-vocational classes. This system continued until 1974 when a committee appointed under the chairmanship of Prof. N. K. Dzobo proposed a new structure of six-year primary and three-year junior secondary school. This system became a nine-year basic education after which pupils sat for the Basic Education Certificate Examination. The new junior secondary system meant a broadening of secondary education in Ghana.

During the phase out of the Continuation School system, parents and teachers alike encouraged their children and students to write the Common Entrance Examination which had become a more credible form of admission into the secondary schools. The Common Entrance Examination was taken by grade six students and some form 1 and 2 students of the middle school system. Successful candidates were enrolled into the secondary schools to pursue a five-year secondary education and a possible two-year sixth form education. In 1987, the Junior Secondary School structure was put in place on a nation-wide basis. The free and compulsory basic education was now 6 years of primary education and 3 years of junior secondary school.

The present structure of education, which starts at the age of 6 years, is a 6-3-3-4 structure representing, 6 years of primary education, 3 years of Junior Secondary School, 3 years of Senior Secondary School and 4 years University course. Naturally students who successfully pass the Senior Secondary School Certificate Examination can also follow courses at a Polytechnic, Teachers Training College or other tertiary institutions.

Basic and Senior Secondary School run a 40 week school year and students are tested using an internal continuous assessment (30\% of final score) and an external examination conducted by the West African Examinations Council (70\% of final score).

\section{THE ROLE OF WAEC IN THE CONDUCT OF GHANA'S NATIONWIDE TERMINAL EXAMINATIONS}

Since the establishment of the West African Examinations Council in 1952, it has been in charge of the conduct of almost all terminal examinations conducted in Ghana. Needless to say, this places a huge responsibility on them as hundreds of thousands of school children take their examinations each year. Their role is huge and can be grouped into three classic zones.

The first, which is the most important part of their work, is the Pre-Exams zone which concentrates on Test development, processing, testing, and safekeeping.

The second zone covers preparation for the exams day, transportation of the examination papers, recruitment and training of invigilators, the conduct of the examination, and the return of solved questions to the custody of WAEC.

The last zone deals with the marking of scripts and the subsequent grading of students and publishing of the results.

\section{MEASURES TAKEN BY WAEC TO ERADICATE EXAMINATION MALPRACTICE}

Needless to say, as with any professional examination body, WAEC has a pool of questions from which it selects what to present to their candidates at any time. So any leakage of questions can be averted or solved by presenting a new set of questions without delay. Aside this, WAEC has taken other steps to eradicate examination malpractice by putting in place a number of steps to ensure the non-occurrence of malpractices in their examinations. In the past, BECE candidates had to carry their own pencils and erasers into the examination halls and this provided a tool for the candidates to cheat. Some will write answers of the Objective Test on papers and insert them into the eraser without notice. These days, students are provided with pencils and erasers at the examination halls. WAEC also provides for counting of all papers by its representatives at the examination centres before the start of any paper. Immediately after the end of any paper, the papers are counted altogether again to ensure that the total number of scripts collected and sent to WAEC are as exactly the same in number as was received. This is to ensure that no part of the examination papers has been removed from the examination centre before and/or after the start of the examination. Police officers accompany the transportation of examination papers to examination centres to ensure its safe delivery. And quite recently, until June 2014, BECE candidates took Paper 1 (Objective Test) first and break for one hour and come back to write Paper 2 (Theory/Essay) of the same subject. Now candidates take Paper 2 and Paper 1 at 
a sit with no break in between them. This means that candidates only leave the examination halls upon completion of a whole subject.

Aside these measures, WAEC have also implemented punitive measures for candidates who still find ways of circumventing these rules and regulations. Mobile Phones are also prohibited at the examination centres and any student found with one at the examination hall will have all his examination results cancelled.

\section{FACTORS AFFECTING THE PROPENSITY TO CHEAT IN THE BECE}

1. The massive ill-preparedness of students for the BECE.

2. Lack of qualified teachers in most private schools.

3. The eagerness of newly qualified schools to prove that their products are the best.

4. To use the results to advertise their schools to attract unsuspecting parents/guardians to bring their wards.

5. Because of the single entry nature of the BECE, students take it as simply unacceptable not to perform well, since there is no other chance to re-sit the examinations.

6. The greedy nature of some WAEC officials to make huge sums of money, hence leaking examination questions.

7. The corrupt nature of some heads of senior high schools to admit students based on a certain almost unachievable score. Hence parents and school authorities have to collaborate to cheat in the examinations so that their wards and products can gain admission into the best schools.

8. The sheer showing of hacking skills by some individuals and to use them to make a living.

\section{THE FORMS OF EXAMINATION MALPRACTICES IN THE BECE.}

The first form of examination malpractice is the leakage of examination questions for profit gain from WAEC workers. People in the ICT department of WAEC are the most cited for leakage of questions from source. They work through agents who in turn work through their sub-agents who contact school proprietors and settle on final price to pay. They even provide option for these proprietors to have the results of their students changed entirely for them before they are released.

WAEC officials who are assigned to send examination questions to examination centres connive with Policemen who accompany them and remove a paper and make photocopy or scan them onto the computer for onward distribution to subscribed schools or proprietors. There are other officials at the examination centre whose primary duty is to keep custody of the examination questions. Such officials are also bribed to undermine the very obligation they are safeguarding.

Some school proprietors also pay huge sums of money to examination centre officials, invigilators, and Policemen to smuggle unauthorised materials into the examination room, specifically, solved questions on sheets of papers for onward forwarding to their students. Every school is now purchasing buses for use under the pretext of transporting their candidates to the examination centres. Inside buses are teachers whose subjects are being written and so smuggled question papers are sent to them for solving. Invigilators bring out the question papers to them inside the school buses that park at obscure corners around the examination centres. These unscrupulous invigilators collect the answers on sheets of papers and send them inside the examination hall for onward distribution to designated students.

Another form of malpractice is the use of mobile phones. Because students face outright cancellation of entire results if found with mobile phones in the examination hall, they now leave them with people around the examination centres and when they are half-way through the Paper 1, they excuse themselves and go out only to look on their phones for the solution to the Paper 1 which are sent after the start of the paper.

\section{FINDINGS AND DISCUSSION OF THE STUDY}

The whole leaking syndrome in the BECE starts a couple of weeks before the start of the examinations. This is usually commenced by advertisements on Facebook, Twitter, and other social media to attract customers, mostly heads of schools and proprietors. Sixteen correspondents adduce to the subscription to these advertisements. The leaking cartel is of two types, first-sourced and second-sourced. First-sourced cartels allege WAEC officers as their main source of the questions, while they send them to second-sourced cartels. It is even believed that second-sourced cartels in turn forward them to other interested cartels usually with the solution to the leaked questions. First-sourced cartels are believed to pay between $\mathrm{GH} \phi 2,000.00$ and $\mathrm{GH} \phi 2,500.00$ per paper and sell them to second-sourced cartels between $\mathrm{GH} \phi 1,000$ and $\mathrm{GH} \varnothing$ 1,500. Most second-sourced cartels usually solve the questions and sell them directly to schools or third-sourced cartels at $\mathrm{GH} \phi 700$ and $\mathrm{GH} \not 1,000$ per paper. With prevailing exchange rate of $1 \mathrm{USD}=3 \mathrm{GH} \phi$, these cartels make huge sums of money yearly and continuously seek for ways of circumventing WAEC's modalities to check cheating in their examinations. Payment of subscription fee is done by mobile money transfer and login details are sent to the phone number that transferred the money to them. Between one hour and four hours to the start of each paper, depending on one's source of the leaked questions, scanned copies of the examination question paper is posted on a secretly created page on a social media. Subscribers then login and wait for the scanned question papers. This has become a booming business and people are making huge sums of money out of it.

As a result of the low ICT skills of most teachers in the country, ICT teachers are made to lead this disgusting and criminal act. School heads and proprietors provide them with laptops, or tablet PCs and the login details and they login to the page. There are times when the papers delay and contacts had to be made to the source of the leakage. On such occasions, even when the ICT teacher calls the source, he will be turned down until they hear from the very person they know, usually proprietors and heads of schools.

Because first-sourced schools receive the question papers in their raw unsolved form, they carry subject teachers along to the examination centre. Immediately the questions drop, these subject teachers solve them on sheets of papers, usually with each question on a separate paper. Students enter the examination hall without these foreign materials, but they are usually smuggled in to the examination hall by invigilators themselves, usually for a small fee from school heads and proprietors. Because supervisors and invigilators know their corrupt duties in the examinations, they purchase photocopiers and hide them in offices to make countless number of copies and distribute them to many candidates. It even came to light that these invigilators go to parents of candidates and demand certain amounts of money with the promise of helping them in the examinations. Teachers in schools where examinations are held usually present themselves to school heads and 
proprietors as being in a position to assist them perpetuate their criminal acts. Most heads and proprietors recruit these teachers as part-time teachers with their schools and serve as conduit for the trafficking of foreign materials into the examination halls. These invigilators take the smuggled papers from students and pass them on to other affiliated students. They make it a point also to collect these materials from the students before they leave the centre. However, there were times when they could not collect them and students leave the examination hall with them.

Even security personnel sent to examination centres assume that their role is to ensure orderliness at the examination centre, but not to prevent malpractices. School proprietors actually make budget for these security personnel to make them indifferent to the malpractices at the centre.

For highly technical subjects such as B.D.T. and I.C.T., and language subjects like local languages and French, finding people with the requisite knowledge is rare. There were times some correspondents had to be sent to their source of the questions to help provide solutions to these technical and language subjects. This provided the unique opportunity for them to interact with the source people. These cartels usually position themselves at examination centres where their students or clients write their papers. They hide in vans and cars at secluded places at the examination centre. If security men are really up to their responsibilities, these cartels can be brought to an end without any difficulty.

In all these machinations to cheat, the results that were obtained by these schools were not far from their previous records in the examinations. This could be as a result of periodic cheating by these schools or their malpractices have little or no effect on the results. The region by region analysis and performance of these schools in the past three years are as shown below;

\subsection{Ashanti Region}

Ashanti has the second largest population and contributes a huge number of candidates each year. It also has the largest number of private schools in Ghana at the Basic Education level. Ashanti always perform among the best three regions in annual rankings in the BECE by the WAEC, Ghana.

Generally, all the five schools performed very well as compared to the average pass rate of the region. The performance of the five schools under study, named A1... A5 are shown in the table below.

Table 2. Three-Year Performance of Schools Under Study in Ashanti Region

\begin{tabular}{|c|c|c|c|c|c|c|}
\hline$\underset{\nu}{\ddot{E}}$ & $\begin{array}{l}\overline{8} \\
\bar{\delta} \\
\tilde{n}\end{array}$ & 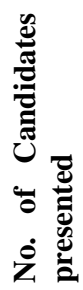 & 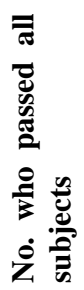 & 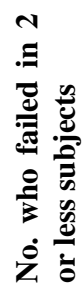 & 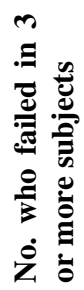 & 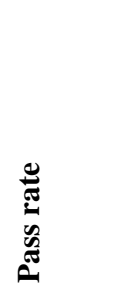 \\
\hline \multirow[t]{5}{*}{2013} & A1 & 28 & 26 & 0 & 2 & $92.86 \%$ \\
\hline & A2 & 10 & 10 & 0 & 0 & $100.00 \%$ \\
\hline & A3 & 44 & 38 & 4 & 2 & $86.36 \%$ \\
\hline & A4 & 36 & 18 & 10 & 8 & $50.00 \%$ \\
\hline & A5 & 21 & 18 & 3 & 0 & $85.71 \%$ \\
\hline \multirow[t]{5}{*}{2012} & A1 & 19 & 15 & 3 & 1 & $78.95 \%$ \\
\hline & $\mathrm{A} 2$ & 7 & 5 & 2 & 0 & $71.43 \%$ \\
\hline & $\mathrm{A} 3$ & 36 & 31 & 4 & 1 & $86.11 \%$ \\
\hline & $\mathrm{A} 4$ & 30 & 12 & 10 & 8 & $40.00 \%$ \\
\hline & A5 & 18 & 14 & 3 & 1 & $77.78 \%$ \\
\hline
\end{tabular}

\begin{tabular}{|l|l|l|l|l|l|l|}
\hline 2011 & A1 & 15 & 11 & 4 & 0 & $73.33 \%$ \\
\cline { 2 - 7 } & A2 & - & - & - & - & - \\
\cline { 2 - 7 } & A3 & 30 & 20 & 6 & 4 & $66.67 \%$ \\
\cline { 2 - 7 } & A4 & 24 & 20 & 3 & 1 & $83.33 \%$ \\
\cline { 2 - 7 } & A5 & 13 & 10 & 3 & 0 & $76.92 \%$ \\
\hline
\end{tabular}

\section{PASS RATE}

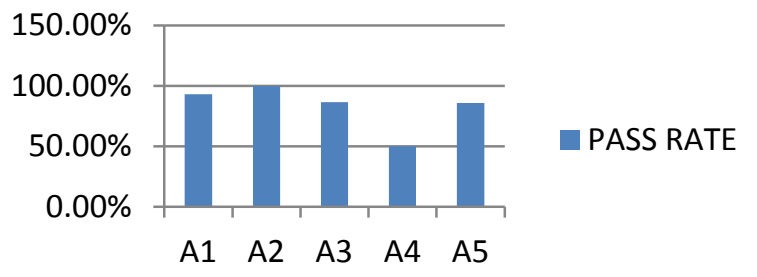

Fig 2: 2013 Pass rate for all five schools under study in Ashanti Region

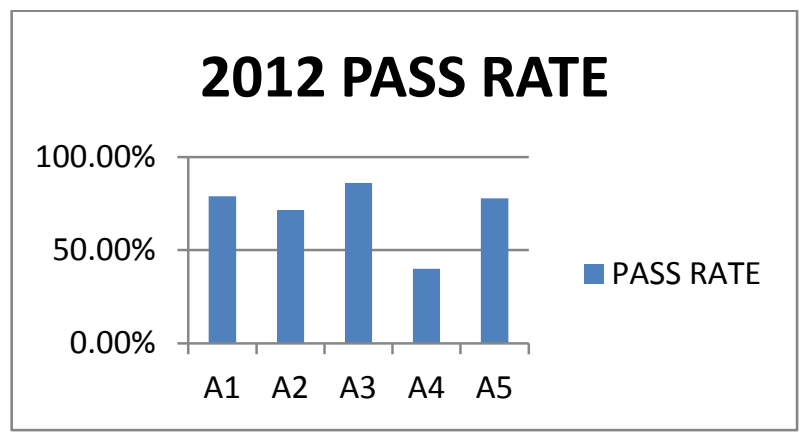

Fig 3: 2012 Pass rate for all five schools under study in Ashanti Region

\section{PASS RATE}

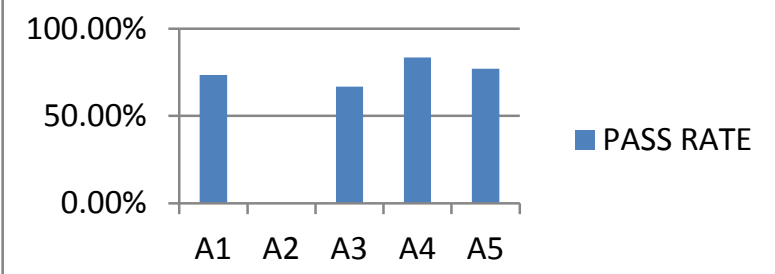

Fig 4: 2011 Pass rate for all five schools under study in Ashanti Region

School A4 became notorious in examination malpractices in the $2011 \mathrm{BECE}$ and for that reason, they had become prime targets by invigilators. It was publicly revealed that the candidates walked into the examination hall without the necessary body searching. As a result, candidates boldly entered the examination hall with foreign materials. With the arrival of a Catholic Nun as a supervisor, school A4 has seen a nose-dive in performance, from $83.33 \%$ in 2011 to $40 \%$ in 2012. There was a marginal increase in 2013 as a result of putting in measures to circumvent the measures instituted to curb their malpractices.

School A1 writes the examination in a Basic school and they have built a close partnership with some of the teachers in those schools who also serve as invigilators to assist in cheating by smuggling solutions to the examination halls while examination is in progress. As a result, they always see 
a rise in performance on yearly basis, an indication that cheating pays.

The remaining schools, A2, A3, and A5 have maintained a relatively stable performance over the years. They have not come across any impediment as they easily pay their way through.

\subsection{Brong Ahafo Region}

Brong-Ahafo region lies in the middle of Ghana and contributes a fair share of candidates each year. They always perform averagely in the BECE but the four schools under study perform exceedingly well above the region's average. The performance of the four schools under study, named B1... B4 are shown in the table below.

Table 3. Three-Year Performance of Schools Under Study in Brong-Ahafo Region

\begin{tabular}{|c|c|c|c|c|c|c|}
\hline \multirow[b]{2}{*}{$\underset{\bar{~}}{\vec{\nabla}}$} & \multirow[b]{2}{*}{ 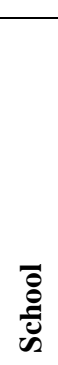 } & & \multirow[b]{2}{*}{ 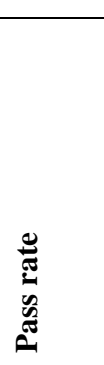 } \\
\hline & & 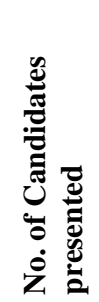 & 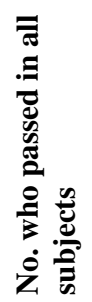 & 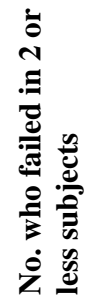 & 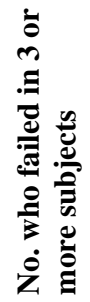 & \\
\hline \multirow[t]{4}{*}{2013} & B1 & 62 & 49 & 11 & 2 & $79.03 \%$ \\
\hline & B2 & 43 & 40 & 2 & 1 & $93.02 \%$ \\
\hline & B3 & 51 & 45 & 4 & 2 & $88.24 \%$ \\
\hline & B4 & 37 & 32 & 3 & 2 & $86.49 \%$ \\
\hline \multirow[t]{4}{*}{2012} & B1 & 58 & 43 & 8 & 7 & $74.14 \%$ \\
\hline & B2 & 40 & 36 & 4 & 0 & $90.00 \%$ \\
\hline & B3 & 52 & 44 & 4 & 4 & $84.62 \%$ \\
\hline & B4 & 40 & 30 & 7 & 3 & $75.00 \%$ \\
\hline \multirow[t]{4}{*}{2011} & B1 & 50 & 43 & 5 & 2 & $86.00 \%$ \\
\hline & B2 & 31 & 28 & 3 & 0 & $90.32 \%$ \\
\hline & B3 & 47 & 38 & 7 & 2 & $80.85 \%$ \\
\hline & B4 & 38 & 28 & 9 & 1 & $73.68 \%$ \\
\hline
\end{tabular}

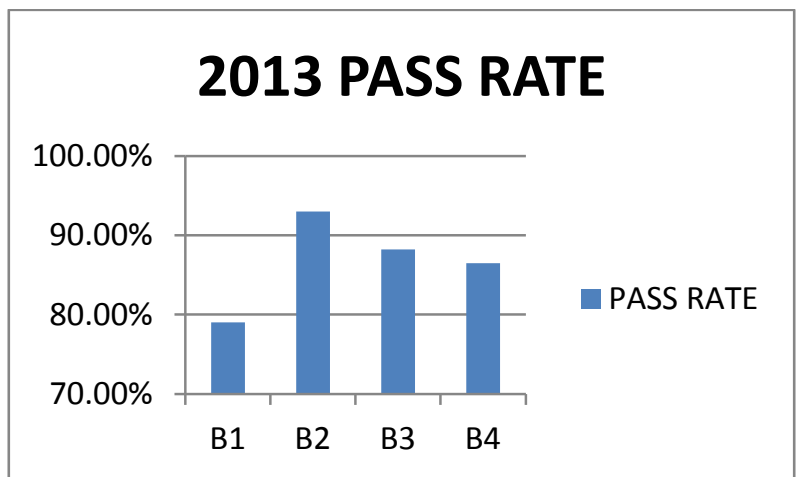

Fig 5: 2013 Pass rate for all four schools under study in Brong Ahafo Region

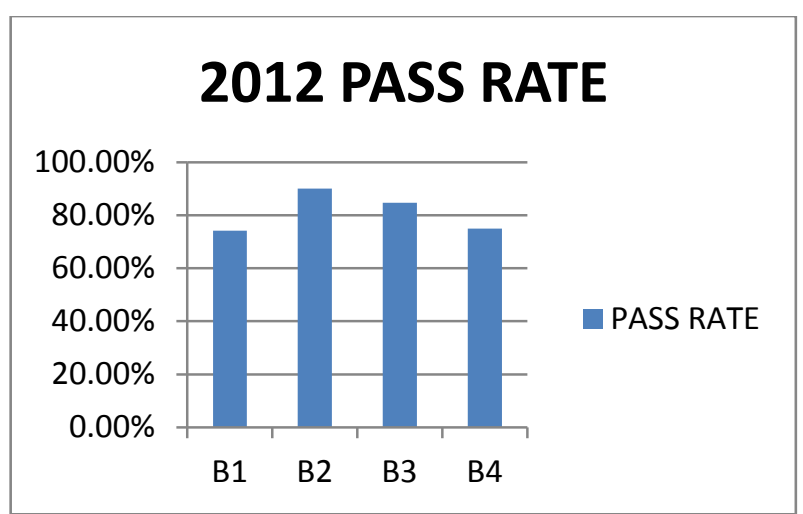

Fig 6: 2012 Pass rate for all four schools under study in Brong Ahafo Region

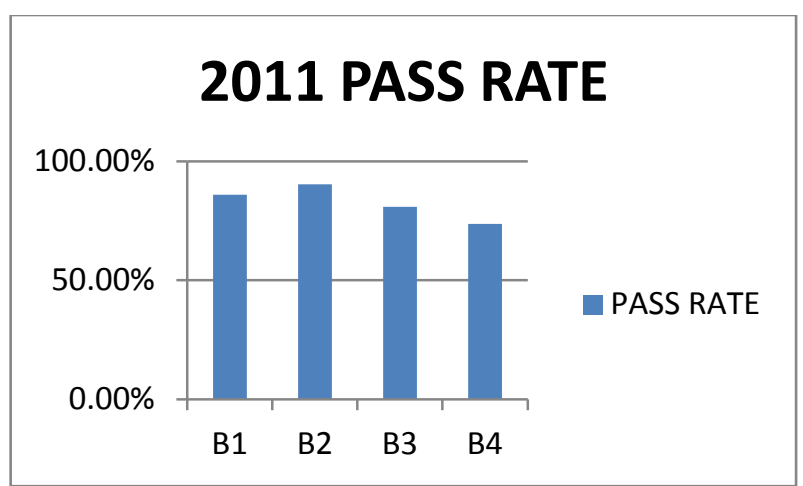

Fig 7: 2011 Pass rate for all four schools under study in Brong Ahafo Region

Brong Ahafo schools seem to have a consistent performance over the three year period. Even when a school drops in performance, efforts are made to apiece for it in later exams.

\subsection{Central Region}

The Central region is the citadel of learning. The number of candidates they present are not too great as their population is small. They are ranked fifth in the number of private schools in Ghana. The performance of the two schools under study, CI and $\mathrm{C} 2$ are presented in the table below.

Table 4. Three-Year Performance of Schools Under Study in Central Region

\begin{tabular}{|c|c|c|c|c|c|c|}
\hline$\stackrel{\bar{\varpi}}{\bar{\nu}}$ & 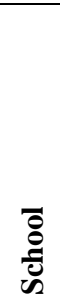 & 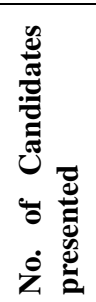 & 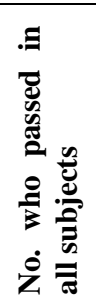 & 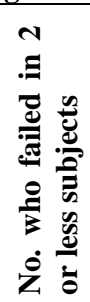 & 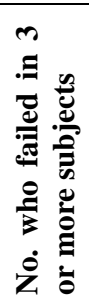 & 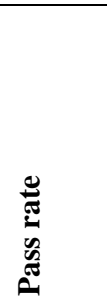 \\
\hline \multirow[t]{2}{*}{2013} & $\mathrm{C} 1$ & 40 & 36 & 3 & 1 & $90.00 \%$ \\
\hline & $\mathrm{C} 2$ & 38 & 30 & 4 & 4 & $78.95 \%$ \\
\hline \multirow[t]{2}{*}{2012} & C1 & 35 & 31 & 3 & 1 & $88.57 \%$ \\
\hline & $\mathrm{C} 2$ & 28 & 20 & 6 & 2 & $71.43 \%$ \\
\hline \multirow[t]{2}{*}{2011} & $\mathrm{C} 1$ & 33 & 27 & 3 & 3 & $81.81 \%$ \\
\hline & $\mathrm{C} 2$ & 25 & 21 & 4 & 0 & $84.00 \%$ \\
\hline
\end{tabular}




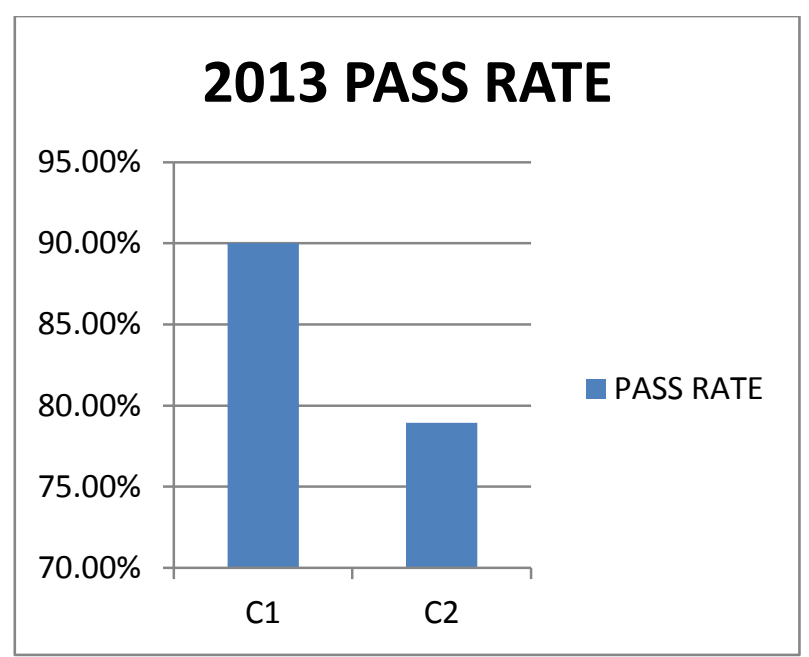

Fig 8: 2013 Pass rate for all two schools under study in Central Region

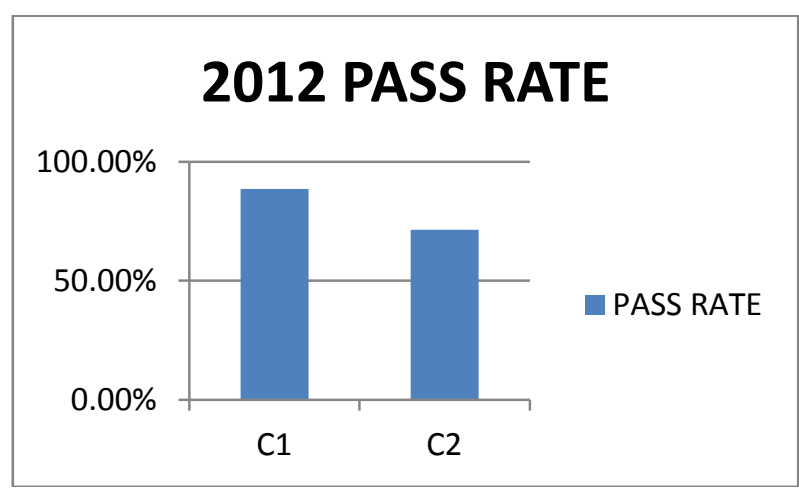

Fig 9: 2012 Pass rate for all two schools under study in Central Region

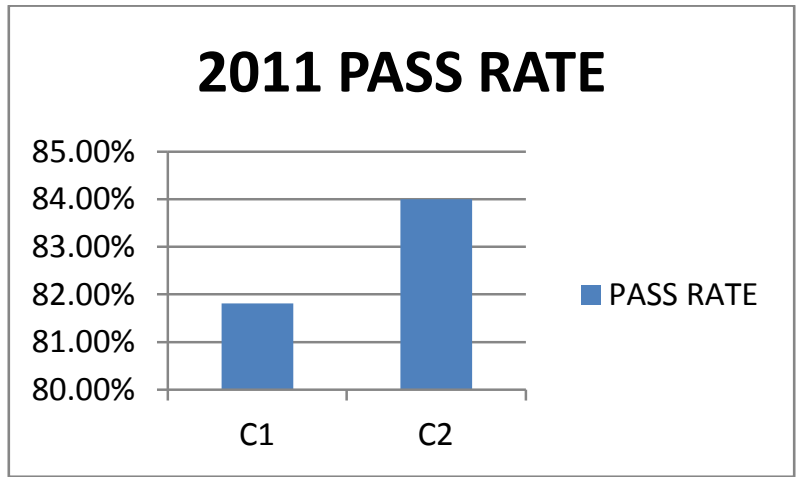

Fig 10: 2011 Pass rate for all two schools under study in Central Region

School CI presented their first candidates in 2011 and the pass rate was above the regional average. However, compared to other private schools, they were simply average. They bought into the cheating scheme and their results has been a far improvement over the region's average. School C2 has been in the business for years and understands the intricacies of the whole malpractice scenario and so performs excellently on annual basis.

\subsection{Eastern Region}

Eastern region also present a significant number of candidates yearly. The selected three schools' performance over the last three years are shown in the table below with the schools named as E1...E3.
Table 5. Three-Year Performance of Schools under study

\begin{tabular}{|c|c|c|c|c|c|c|}
\hline \multicolumn{7}{|c|}{ in Eastern Region } \\
\hline 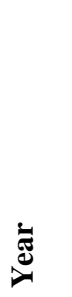 & 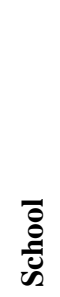 & 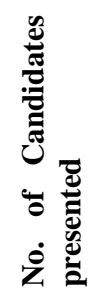 & 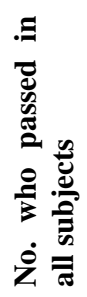 & 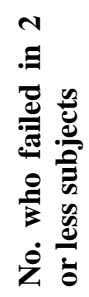 & 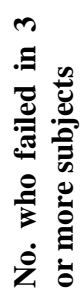 & 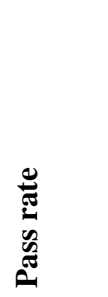 \\
\hline \multirow[t]{3}{*}{2013} & E1 & 31 & 28 & 2 & 1 & $90.32 \%$ \\
\hline & E2 & 28 & 26 & 1 & 1 & $92.86 \%$ \\
\hline & E3 & 35 & 30 & 3 & 2 & $85.71 \%$ \\
\hline \multirow[t]{3}{*}{2012} & E1 & 30 & 23 & 4 & 3 & $76.67 \%$ \\
\hline & E2 & 30 & 24 & 5 & 1 & $80.00 \%$ \\
\hline & E3 & 32 & 28 & 3 & 1 & $87.50 \%$ \\
\hline \multirow[t]{3}{*}{2011} & E1 & 22 & 19 & 3 & 0 & $86.36 \%$ \\
\hline & E2 & 25 & 20 & 3 & 2 & $80.00 \%$ \\
\hline & E3 & 28 & 25 & 2 & 1 & $89.29 \%$ \\
\hline
\end{tabular}

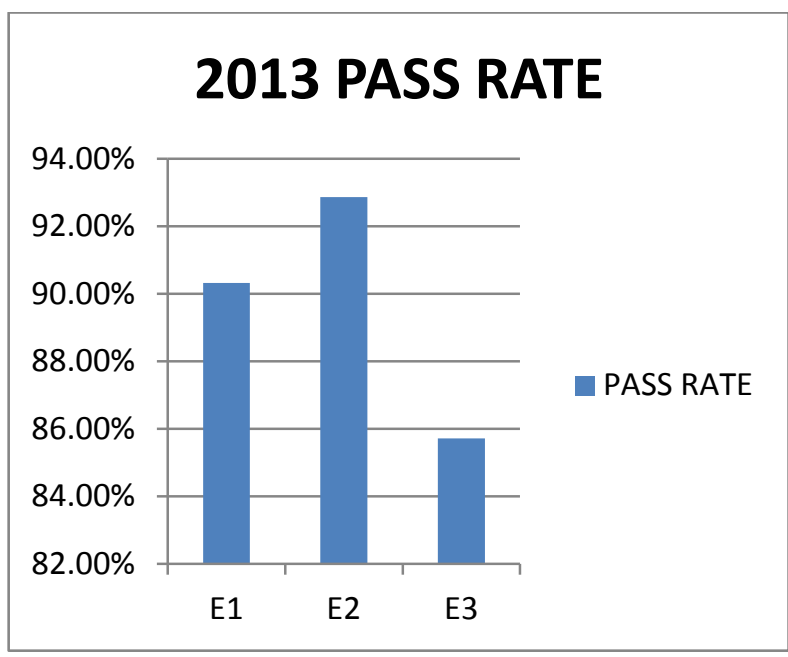

Fig 11: 2013 Pass rate for all three schools under study in Eastern Region

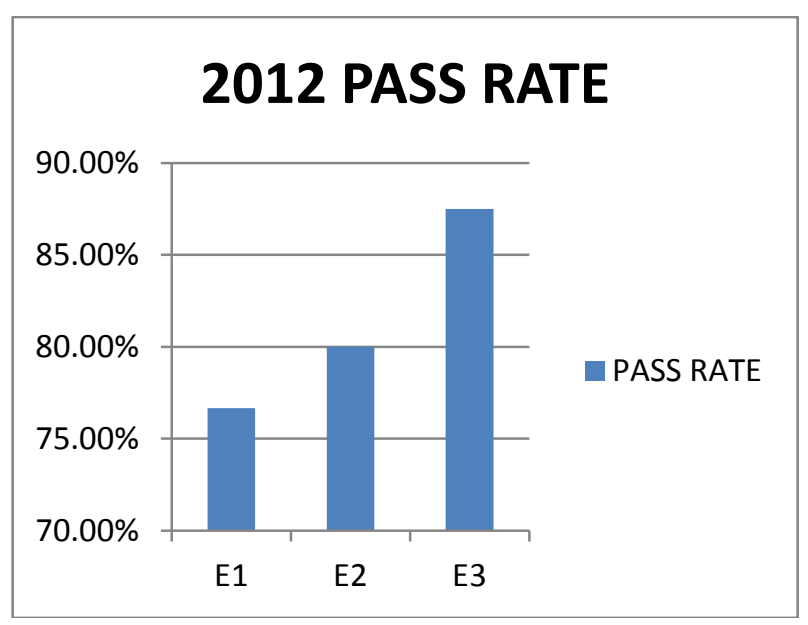

Fig 12: 2012 Pass rate for all three schools under study in Eastern Region 


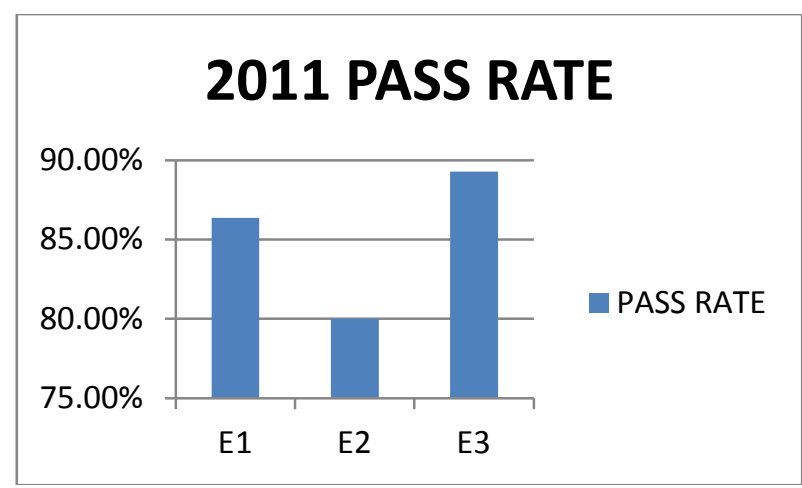

Fig 13: 2011 Pass rate for all three schools under study in Eastern Region

School E2 has seen a remarkable increase in performance over the three-year period and is known very well in the region. It's performance shot up to $92.86 \%$ in 2013 from a value of $80 \%$ in 2011 and 2012.

School E3 has seen a marginal decrease in pass rate from $89.29 \%$ in 2011 to $87.50 \%$ in 2012 and $85.71 \%$ in 2013 . However, each year, they far perform better than the region's average.

\subsection{Greater Accra Region}

Rated as the most populous region, Accra ranks within the first three when it comes to number of candidates as well as performance. The three schools surveyed are represented as G1...G3 in the table below.

Table 6. Three-Year Performance of Schools Under Study

\begin{tabular}{|c|c|c|c|c|c|c|}
\hline$\stackrel{\vec{\nexists}}{\ddot{Z}}$ & $\begin{array}{l}\overline{8} \\
\overline{0} \\
\overline{0}\end{array}$ & 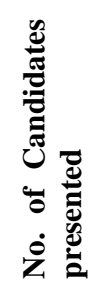 & 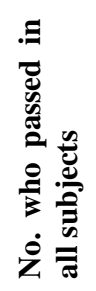 & 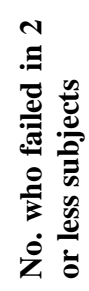 & 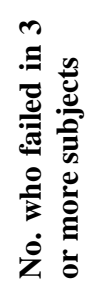 & 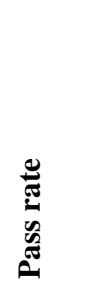 \\
\hline \multirow[t]{3}{*}{2013} & G1 & 52 & 40 & 8 & 4 & $76.92 \%$ \\
\hline & G2 & 40 & 36 & 4 & 0 & $90.00 \%$ \\
\hline & G3 & 33 & 29 & 3 & 1 & $87.88 \%$ \\
\hline \multirow[t]{3}{*}{2012} & G1 & 48 & 44 & 4 & 0 & $91.67 \%$ \\
\hline & G2 & 42 & 36 & 5 & 1 & $85.71 \%$ \\
\hline & G3 & 38 & 28 & 8 & 2 & $73.68 \%$ \\
\hline \multirow[t]{3}{*}{2011} & G1 & 40 & 33 & 5 & 2 & $82.50 \%$ \\
\hline & G2 & 36 & 31 & 3 & 2 & $86.11 \%$ \\
\hline & G3 & 30 & 28 & 2 & 0 & $93.33 \%$ \\
\hline
\end{tabular}

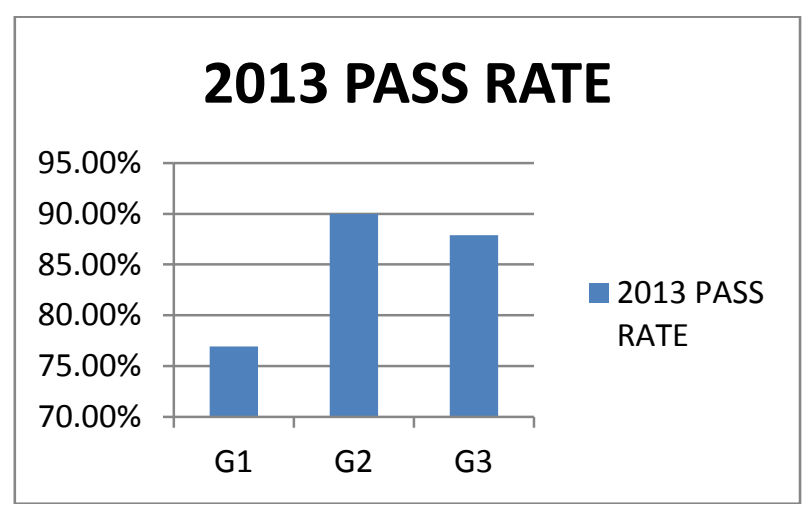

Fig 14: 2013 Pass rate for all three schools under study in Greater Accra Region

\section{PASS RATE}

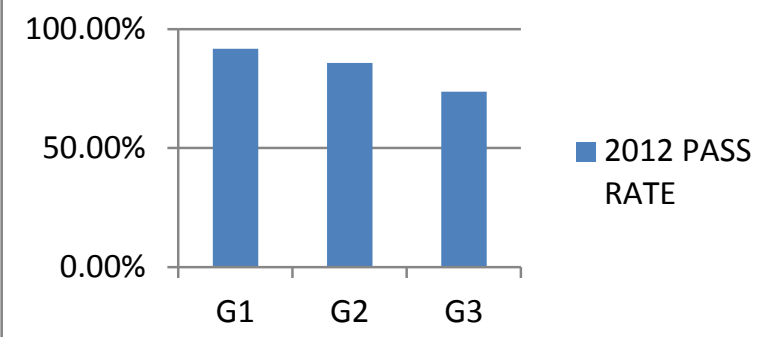

Fig 15: 2012 Pass rate for all three schools under study in Greater Accra Region

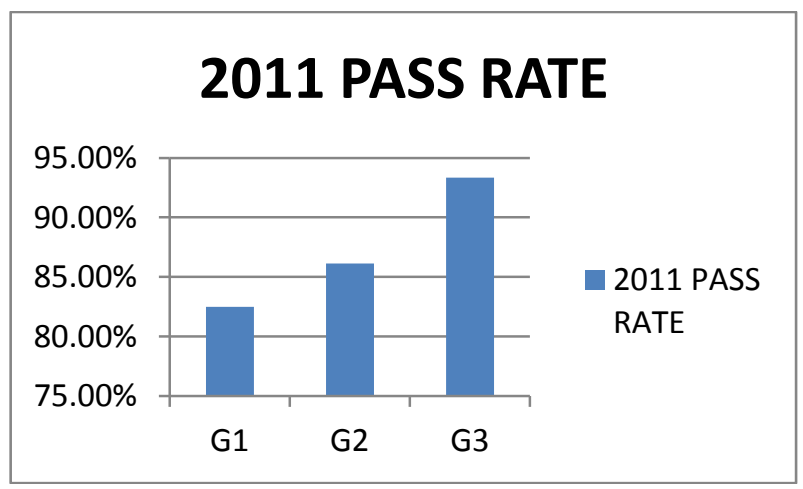

Fig 16: 2011 Pass rate for all three schools under study in Greater Accra Region

All the schools in Greater Accra surveyed, have a kind of fluctuating performance. However, the results are pretty average compared to other private schools in the region.

\subsection{Northern Region}

This region has the largest land size but has a few number of people residing there. As a result, it is ranked among the last four schools in terms of contribution of candidates to the examinations. The three schools under survey are represented as N1...N3.

Table 7. Three-Year Performance of Schools Under Study in Northern Region

\begin{tabular}{|c|c|c|c|c|c|c|}
\hline$\underset{\varpi}{\overparen{\Xi}}$ & 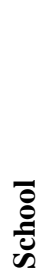 & 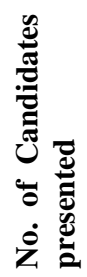 & 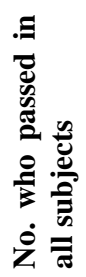 & 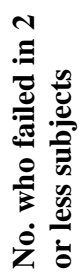 & 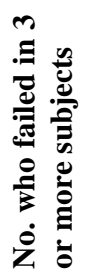 & 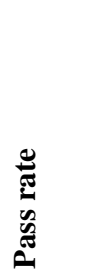 \\
\hline \multirow[t]{3}{*}{2013} & N1 & 30 & 20 & 3 & 7 & $66.67 \%$ \\
\hline & N2 & 43 & 38 & 4 & 1 & $88.37 \%$ \\
\hline & N3 & 35 & 31 & 3 & 1 & $88.57 \%$ \\
\hline \multirow[t]{3}{*}{2012} & N1 & 32 & 22 & 6 & 4 & $68.75 \%$ \\
\hline & $\mathrm{N} 2$ & 40 & 36 & 4 & 0 & $90.00 \%$ \\
\hline & N3 & 31 & 28 & 3 & 0 & $90.32 \%$ \\
\hline \multirow[t]{3}{*}{2011} & N1 & 20 & 14 & 5 & 1 & $70.00 \%$ \\
\hline & N2 & 38 & 36 & 1 & 1 & $94.74 \%$ \\
\hline & N3 & 33 & 26 & 5 & 2 & $78.79 \%$ \\
\hline
\end{tabular}




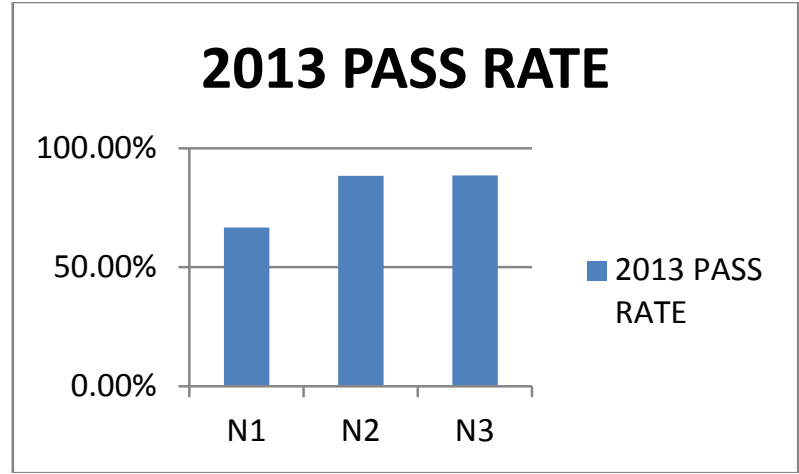

Fig 17: 2013 Pass rate for all three schools under study in Northern Region

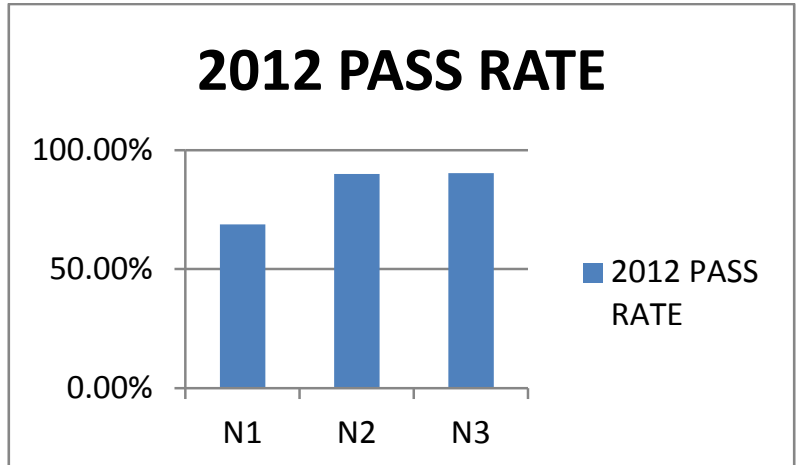

Fig 18: 2012 Pass rate for all three schools under study in Northern Region

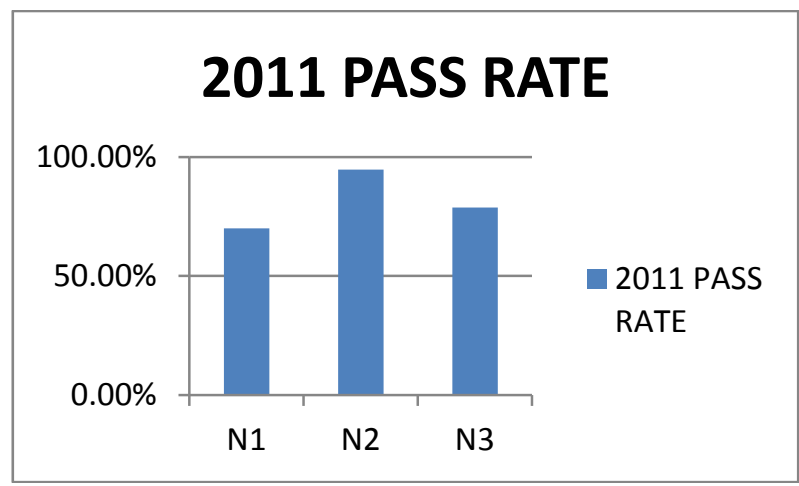

Fig 19: 2011 Pass rate for all three schools under study in Northern Region

School N2 has seen its excellent performance dip over the three-year period. From an impressive performance of $94.74 \%$ in 2011 to $90.00 \%$ in 2012 and further drop to $88.37 \%$ in 2013 signifies a drop in degree of cheating. The same trend is exhibited by school N1 with $70.00 \%$ in 2011 to $68.75 \%$ in 2012 and a further drop to $66.67 \%$ in 2013 . This is made possible by a rigorous mechanism put in place to prevent them from cheating. However, school N1 has a kind of not so much deviation from the norm. All schools performed above the regional average.

\subsection{Upper East Region}

It is youngest twin region and has the smallest land size after Upper West. Its population is small with fewer number of candidates presented each year. The region also has the least number of private schools. The school surveyed are named UE1 and UE2.
Table 8. Three-Year Performance of Schools Under Study

\begin{tabular}{|c|c|c|c|c|c|c|}
\hline \multicolumn{7}{|c|}{ in Upper East Region } \\
\hline 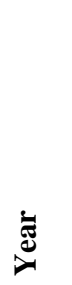 & 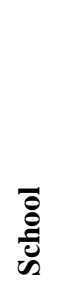 & 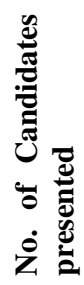 & 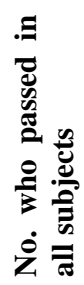 & 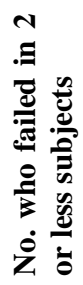 & 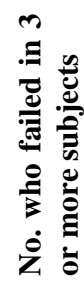 & 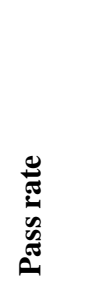 \\
\hline \multirow[t]{2}{*}{2013} & UE1 & 22 & 18 & 2 & 2 & $81.82 \%$ \\
\hline & UE2 & 20 & 15 & 3 & 2 & $75.00 \%$ \\
\hline \multirow[t]{2}{*}{2012} & UE1 & 25 & 16 & 5 & 4 & $64.00 \%$ \\
\hline & UE2 & 17 & 12 & 4 & 1 & $70.59 \%$ \\
\hline \multirow[t]{2}{*}{2011} & UE1 & 15 & 12 & 3 & 0 & $80.00 \%$ \\
\hline & UE2 & 13 & 11 & 1 & 1 & $84.62 \%$ \\
\hline
\end{tabular}

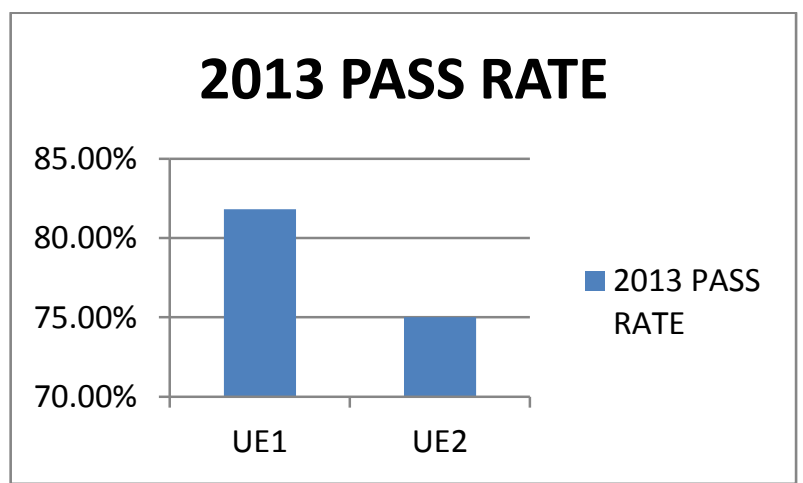

Fig 20: 2013 Pass rate for all two schools under study in Upper East Region

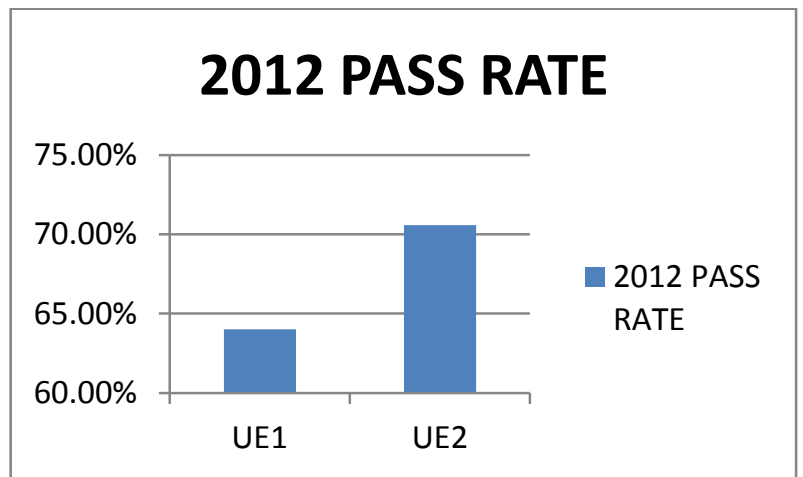

Fig 21: 2012 Pass rate for all two schools under study in Upper East Region

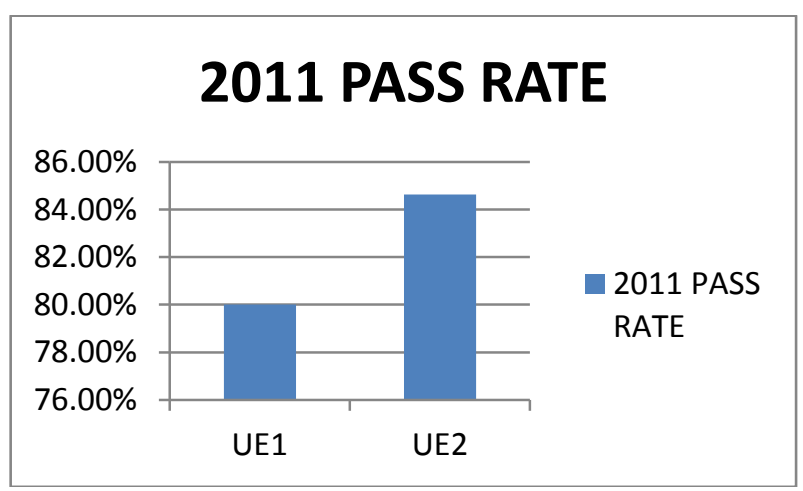

Fig 22: 2011 Pass rate for all two schools under study in Upper East Region 
Both schools under review experiences ups and downs in the examinations. Reasons that account for this include the unwillinglness of proprietors to meet the demands of invigilators at times, and so corporation is limited at times.

\subsection{Upper West Region}

This region is the smallest inland size also has a very few number of private schools. The two schools used for the survey are represented as UW1 and UW2, and their performance in the BECE in the last three years are presented in the table below.

Table 9. Three-Year Performance of Schools Under Study

\begin{tabular}{|c|c|c|c|c|c|c|}
\hline \multicolumn{7}{|c|}{ in Upper West Region } \\
\hline$\stackrel{\bar{\Xi}}{\grave{d}}$ & $\begin{array}{l}\overline{8} \\
\bar{d} \\
\bar{e}\end{array}$ & 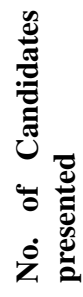 & 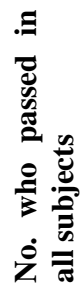 & 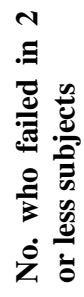 & 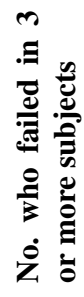 & 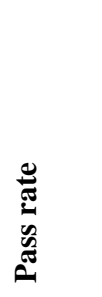 \\
\hline \multirow[t]{2}{*}{2013} & UW1 & 33 & 29 & 4 & 0 & $87.88 \%$ \\
\hline & UW2 & 18 & 17 & 1 & 0 & $94.44 \%$ \\
\hline \multirow[t]{2}{*}{2012} & UW1 & 26 & 23 & 2 & 1 & $88.46 \%$ \\
\hline & UW2 & 21 & 11 & 8 & 2 & $52.38 \%$ \\
\hline \multirow[t]{2}{*}{2011} & UW1 & 23 & 17 & 3 & 3 & $73.91 \%$ \\
\hline & UW2 & 20 & 17 & 1 & 2 & $85.00 \%$ \\
\hline
\end{tabular}

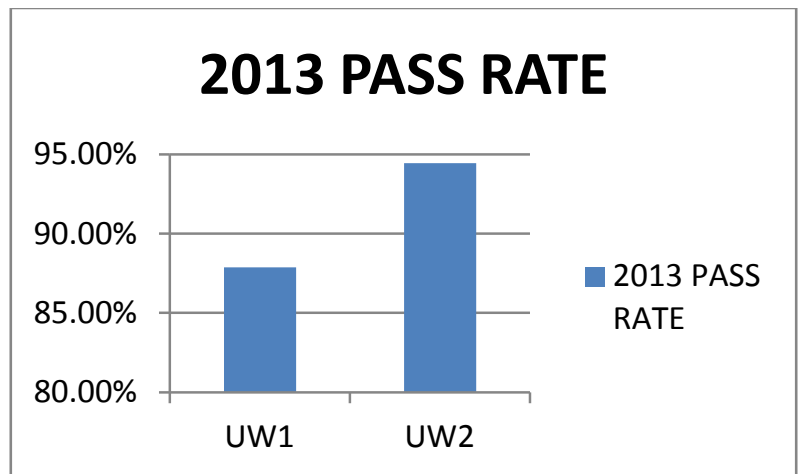

Fig 23: 2013 Pass rate for all two schools under study in Upper West Region

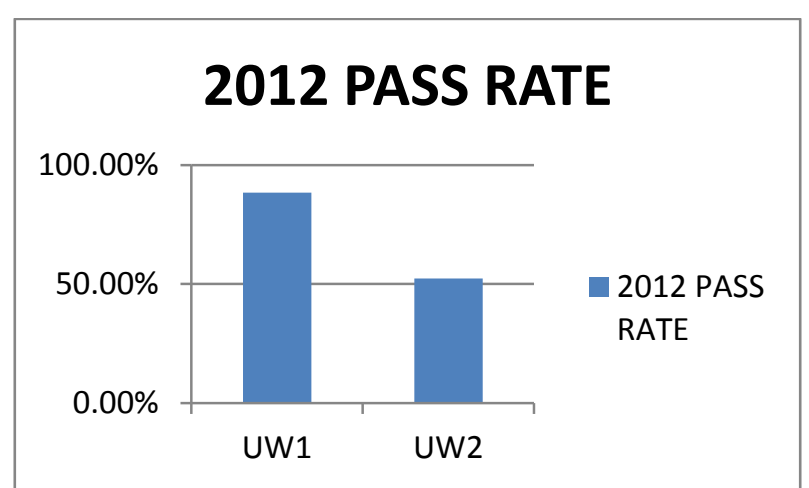

Fig 24: 2012 Pass rate for all two schools under study in Upper West Region

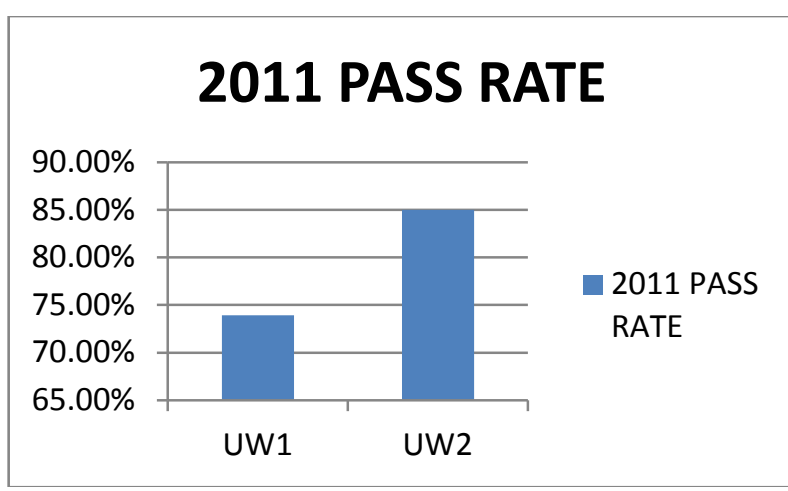

Fig 25: 2011 Pass rate for all two schools under study in Upper West Region

School UW1 exhibits a continuous appreciation of performance yearly, an indication that they are stepping up the cheating game. School UW2 suffered in 2012 for the simple reason that they could not agree on the amount to give be given to the invigilators.

\subsection{Volta Region}

Volta region also contributes a significant number of candidates each year for the BECE. The schools chosen for the survey are represented as V1, V2, and V3. Their performance for the last three years in the BECE is presented in the table below.

Table 10. Three-Year Performance of Schools Under Study in Volta Region

\begin{tabular}{|c|c|c|c|c|c|c|}
\hline$\underset{\nabla}{\ddot{~}}$ & $\begin{array}{l}\bar{O} \\
\overline{0} \\
\bar{\delta}\end{array}$ & 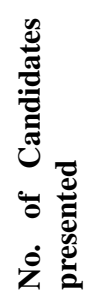 & 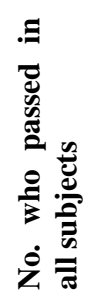 & 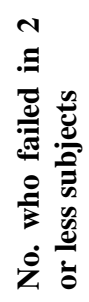 & 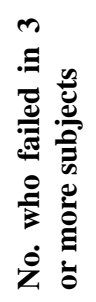 & 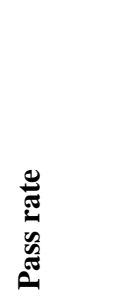 \\
\hline \multirow[t]{3}{*}{2013} & V1 & 41 & 37 & 4 & 0 & $90.24 \%$ \\
\hline & $\mathrm{V} 2$ & 28 & 28 & 0 & 0 & $100.00 \%$ \\
\hline & V3 & 25 & 24 & 1 & 0 & $96.00 \%$ \\
\hline \multirow[t]{3}{*}{2012} & V1 & 38 & 33 & 3 & 2 & $86.84 \%$ \\
\hline & $\mathrm{V} 2$ & 26 & 20 & 5 & 1 & $76.92 \%$ \\
\hline & V3 & 23 & 19 & 3 & 1 & $82.61 \%$ \\
\hline \multirow[t]{3}{*}{2011} & V1 & 33 & 25 & 6 & 2 & $75.76 \%$ \\
\hline & $\mathrm{V} 2$ & 21 & 17 & 4 & 0 & $80.95 \%$ \\
\hline & V3 & 22 & 15 & 4 & 3 & $68.18 \%$ \\
\hline
\end{tabular}

\section{PASS RATE}

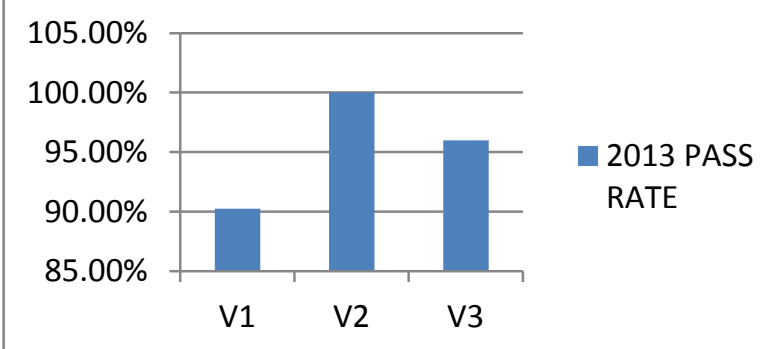

Fig 26: 2013 Pass rate for all three schools under study in Volta Region 


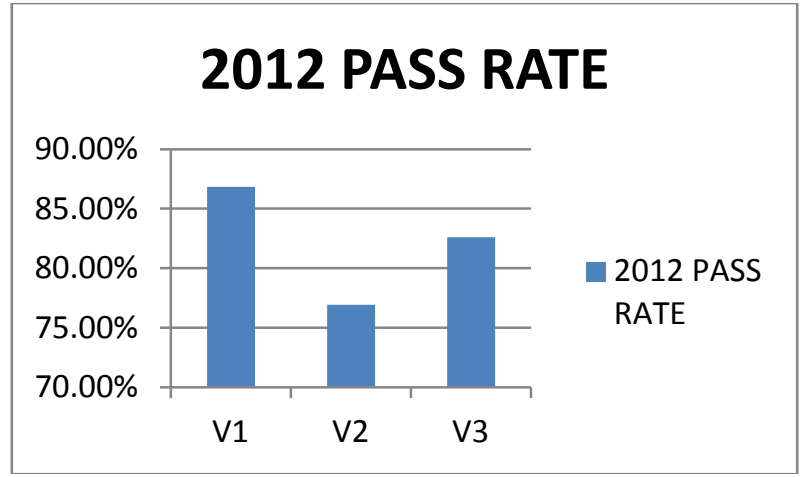

Fig 27: 2012 Pass rate for all three schools under study in Volta Region

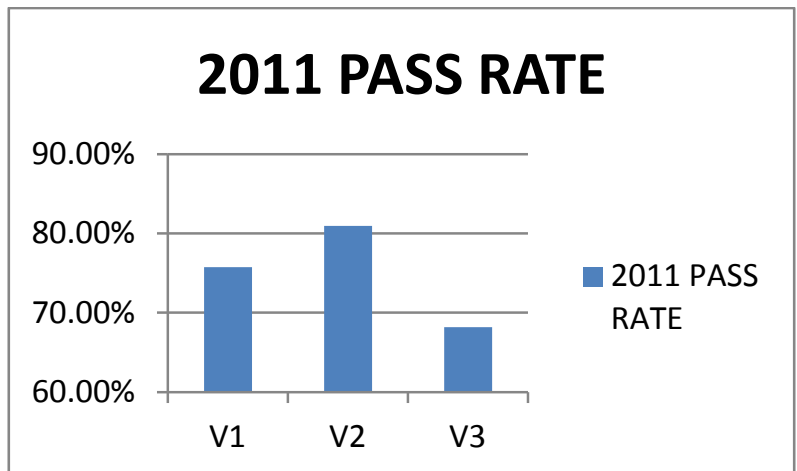

Fig 28: 2011 Pass rate for all three schools under study in Volta Region

School V3 has seen a significant rise in pass rate over the last three years from a pass rate of $68.18 \%$ in 2011 to $82.61 \%$ in 2012 , and $96.00 \%$ in 2013 . This achievement is based on no other factor than conniving with examination centre officials. School V1 also has a continuous rise in pass rate for the last three years, from $75.76 \%$ in 2011 , to 76.92 in 2012 and $90.24 \%$ in 2013. School V2 experienced a drop in pass rate from $80.95 \%$ in 2011 to $76.92 \%$ in 2012 . It however stepped up its game and achieved an excellence pass rate of $100 \%$.

\subsection{Western Region}

This region also contributes a significant number of candidates each year. The three schools chosen are represented as $\mathrm{W} 1, \mathrm{~W} 2$, and $\mathrm{W} 3$ and their performance in the last three years are presented in the table below.

Table 11. Three-Year Performance of Schools Under Study in Western Region

\begin{tabular}{|c|c|c|c|c|c|c|}
\hline 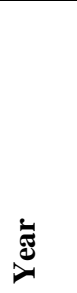 & $\begin{array}{l}\overline{8} \\
\stackrel{8}{0} \\
\bar{\delta}\end{array}$ & 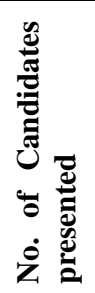 & 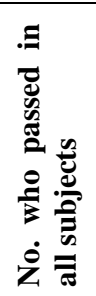 & 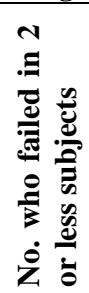 & 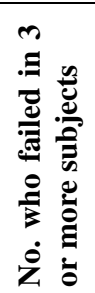 & 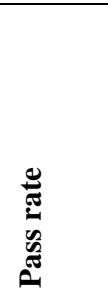 \\
\hline \multirow[t]{3}{*}{2013} & W1 & 22 & 20 & 2 & 0 & $90.91 \%$ \\
\hline & W2 & 18 & 14 & 3 & 1 & $77.78 \%$ \\
\hline & W3 & 40 & 33 & 6 & 1 & $82.50 \%$ \\
\hline \multirow[t]{3}{*}{2012} & W1 & 23 & 20 & 3 & 0 & $86.96 \%$ \\
\hline & W2 & 21 & 17 & 3 & 1 & $80.95 \%$ \\
\hline & W3 & 34 & 28 & 4 & 2 & $82.35 \%$ \\
\hline \multirow[t]{3}{*}{2011} & W1 & 18 & 15 & 3 & 0 & $83.33 \%$ \\
\hline & W2 & 13 & 10 & 1 & 2 & $76.92 \%$ \\
\hline & W3 & 35 & 27 & 5 & 2 & $77.14 \%$ \\
\hline
\end{tabular}

\section{PASS RATE}

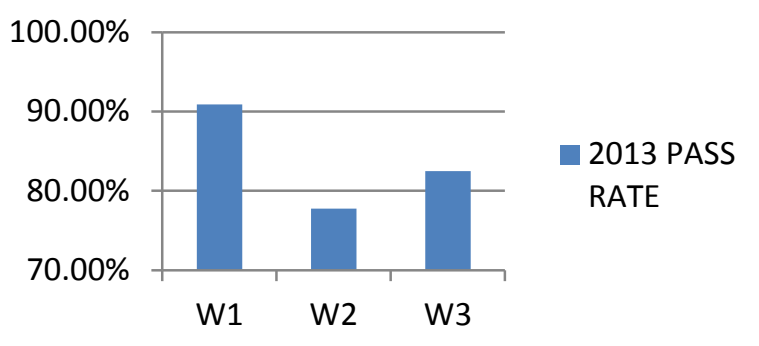

Fig 29: 2013 Pass rate for all three schools under study in Western Region

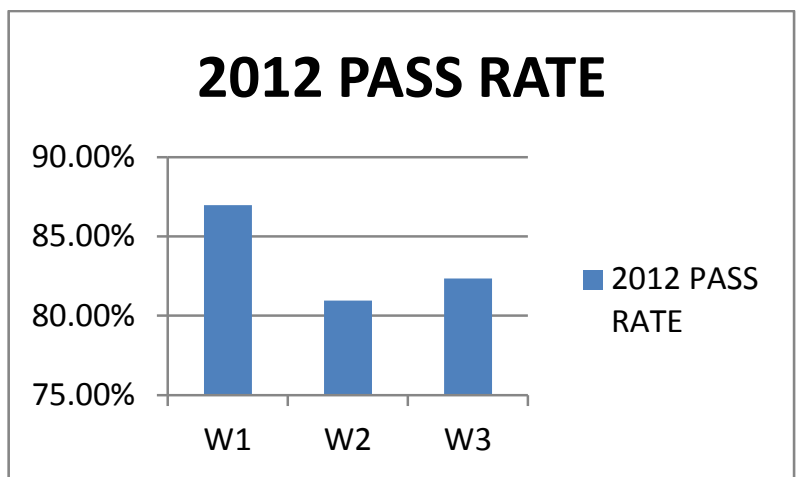

Fig 30: 2012 Pass rate for all three schools under study in Western Region

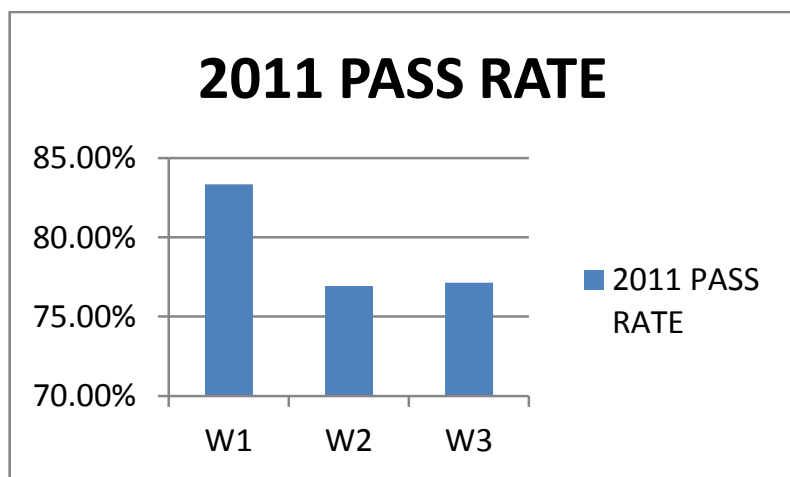

Fig 31: 2011 Pass rate for all three schools under study in Western Region

School W3 has seen a gradual rise in pass rate over the threeyear period from $77.14 \%$ 1n 2011 to $82.35 \%$ in 2012 and $82.50 \%$ in 2013. School W1 also had $83.33 \%$ in 2011, $86.96 \%$ in 2012 , and $90.91 \%$ in 2013. School W2 saw marginal drop in pass rate in 2013 with $77.78 \%$ after increasing from $76.92 \%$ in 2011 to $80.95 \%$ in 2012 .

\section{CONC LUSIONS}

1. WAEC officials are themselves a major part of the examination leaking syndicate.

2. People have formed cartels to leak the examination questions for monetary gains.

3. Proprietors of schools are in constant collaboration with these cartels to obtain the questions before the start of the examination. 
4. Leaked papers are mainly distributed via Social media such as Facebook, Twitter, Whatsapp, etc. and mobile telecommunications via SMS.

5. Invigilators act as conduit between the cheating students and the smuggling of the solution to the examination questions.

6. Compound names of students are split deliberately to either place them at a desired position in the examination hall, either to be helped by brighter students or to help weaker students.

7. Delay times for starting the examination papers from one centre to the other makes the leaking of papers very easy and rampant.

8. Private schools allow their premises to be used as examination centres primarily to obtain a high advantage to cheat.

9. Continuous effort to improvise and solidify cheating is being invested to by school proprietors to achieve excellent results to convince the unsuspecting general public to bring their wards to their schools.

\section{RECOMMENDATIONS}

1. WAEC should work progressively to remove the human element in the conduct of its examinations.

2. Government should permit internet censorship during the conduct of WAEC examinations.

3. WAEC should collaborate with telecommunication companies to monitor the phones of all stake-holders in their examinations during the conduct of the BECE.

4. Index numbers should no longer be distributed on school by school basis. All schools designated to one examination centre should have their students put in one pool and index numbers issued accordingly. This will prevent the passing of answers among students because the person next to you will be completely unknown to you.

5. All students should be seated one hour before the start of the examination. Any student who fails to obey this without tangible reason should be subjected to thorough search by invigilators before entry is allowed.

6. Choice of examination centre should take cognisance of the encloseabillity of the centre. No invigilator or supervisor should be allowed to leave the examination centre once they enter the centre, and no other person should be allowed entry into the examination centre without prior permission from the man-in-charge at the centre.
7. Any school that allows its premises and facilities to be used as an examination centre should not be allowed to write their examinations at that centre.

8. Invigilators must be searched thoroughly when they return to the examination hall after leaving the hall. This will prevent the smuggling of foreign material into the examination hall by them.

9. External supervisors should also conduct periodic thorough search on suspected invigilators because invigilators collect and put all the foreign materials into their pockets when they notice the arrival of an external supervisor.

10. External supervisors should also call for recount of examination scripts when they arrive because there are times when a copy is smuggled out for solving.

11. Invigilators should be rotated yearly from one examination centre to the other. This will prevent the breeding of familiarity between invigilators and participating schools, so that cheating will be minimized significantly.

12. WAEC should employ mechanisms to monitor the performance of suspected schools so that they can query such schools over huge unsuspecting pass rates.

\section{REFERENCES}

[1] Onuka A.O.U. 2009. Stakeholders' Perception of Test Security as Management Tool for Curbing Malpractices in the Nigerian Examining System. African Journal of Educational Management. 12(1)

[2] Kofi Mereku. 2000. The BECE Grading System Committee Report: Implications for Minimum Educational Qualifications for Basic Education Certificate.

[3] WAEC-West African Examinations Council. 2009. Registrar's Annual Report To Council For The Period April 1, 2008 To March 31, 2009.

[4] Onuka A.O.U. 2011. Distance Learner's Time Management. InTech Publishers, Croatia.

[5] Daily Graphic. 2013. Collective Action Necessary to Stem BECE Malpractices. January 16.

[6] United Nations Development Programme (UNDP), United Nations Office on Drugs and Crime (UNODC). 2009. Corruption, a crime against development (www.yourno-counts.org, Retrieved on $10^{\text {th }}$ June 2013.

[7] Ake Gronlund et al. 2010. Increasing Transparency and Fighting Corruption Through ICT: Empowering People and Communities. The Swedish Program for ICT in Developing Regions. 